\title{
Post-synthesis of hierarchically structured Ti- $\beta$ zeolites and their epoxidation catalytic performance
}

\author{
Wenchao Ren, Zile Hua*, Tongguang Ge, Xiaoxia Zhou, Lisong Chen, Yan Zhu, Jianlin Shi \# \\ State Key Laboratory of High Performance Ceramics and Superfine Microstructure, Shanghai Institute of Ceramics, Chinese Academy of Sciences, \\ Shanghai 200050, China
}

\section{A R T I C L E I N F O}

Article history:

Received 3 November 2014

Accepted 15 December 2014

Published 20 June 2015

\section{Keywords:}

Ti-beta

Post-synthesis

Hierarchical porosity

Epoxidation

Zeolite

\begin{abstract}
A B S T R A C T
Hierarchically structured Ti- $\beta$ zeolites were prepared using a two-step post-synthesis approach. The physicochemical properties of the resultant Ti- $m \beta$-Sx materials were determined using various techniques, including X-ray diffraction, scanning electron microscopy, inductively coupled plasma atomic emission spectroscopy, transmission electron microscopy, and ultraviolet-visible and ultraviolet-Raman spectroscopies. The porous structures of the synthesized hierarchical Ti- $\beta$ zeolites were well preserved. Their catalytic performance was compared with that of pure microporous Ti- $\beta$ materials using alkene epoxidation as a model reaction. It was found that although comparable catalytic activities were obtained for both types of catalyst in the epoxidation of small molecules, e.g., cyclohexene, the synthesized hierarchical Ti- $\beta$ gave an enhanced catalytic performance in the epoxidation of bulky 1-dodecene.
\end{abstract}

(C) 2015, Dalian Institute of Chemical Physics, Chinese Academy of Sciences. Published by Elsevier B.V. All rights reserved.

\section{Introduction}

The epoxidation of organic compounds is widely used in the chemical industry, and it is important to find suitable heterogeneous catalysts that work under mild conditions with alkyl hydroperoxides or $\mathrm{H}_{2} \mathrm{O}_{2}$ [1,2]. Much attention has been paid to Ti-containing $\beta$ zeolites, which were first reported by Corma and co-workers [3]. Because of their large 12-ring pore channels, Ti- $\beta$ zeolites are more efficient than TS- 1 in the oxidation of bulky molecules [4]; for example, Rhee et al. [5] reported that Ti- $\beta$ zeolites were twice as efficient as TS- 1 in cyclohexene epoxidation.

Although Ti- $\beta$ zeolites are more accessible to reactants than TS-1, diffusion in microporous structures is still a problem [6].
To solve this problem, attention has recently focused on hierarchical Ti-containing silicate zeolites. Template-directed synthesis using hard or soft templates is often used for the preparation of hierarchical Ti-containing silicate zeolites. Li et al. [7] used a hard-templating process to synthesize a series of hierarchical TS-1 materials with carbon nanoparticles formed in situ by sucrose carbonization. Su and co-workers [8] used a quasi-solid-state crystallization process to prepare new hierarchical micro-meso-macroporous TS-1 zeolites, which showed much higher activities in the epoxidation of 2,4,6-trimethylstyrene and had superior thermal stabilities and reusabilities compared with TS-1 nanoparticles. Recently, we used the steam-assisted crystallization method to synthesize hierarchical TS-1 zeolites, with in situ-polymerized triethanolamine

\footnotetext{
* Corresponding author. Tel: +86-21-52412708; Fax: +86-21-52413122; E-mail: huazl@mail.sic.ac.cn

\# Corresponding author. Tel: +86-21-52412712; Fax: +86-21-52413122; E-mail: jlshi@mail.sic.ac.cn

This work was supported by the National Basic Research Program of China (2013CB933200), the High Technology Research and Development Program of China (2012AA062703), China National Funds for Distinguished Young Scientists (51225202), and the Opening Projects of State Key Laboratory of Heavy Oil Processing (SKLOP201402003).

DOI: 10.1016/S1872-2067(14)60267-9 | http://www.sciencedirect.com/science/journal/18722067 | Chin. J. Catal., Vol. 36, No. 6, June 2015
} 
as mesoporous templates. The resultant materials had high activities and excellent stabilities in the selective catalytic oxidation of 2,3,6-trimethylphenol to 2,3,5-trimethyl- $p$-benzoquinone [9]. However, although hierarchical $\beta$ zeolites with various $\mathrm{Al}$ contents were reported by Bein et al. [10], the synthesis of hierarchical Ti- $\beta$ zeolites is still a challenge.

Secondary synthesis, including isomorphous substitution and atom planting, is a general procedure for the preparation or modification of microporous zeolites that are hard to obtain via direct processing. Chemical vapor deposition (CVD) is often used for the secondary synthesis of Ti- $\beta$ zeolites [11], and liquid- or solid-phase isomorphous substitutions have also been reported [12,13]. When CVD is used, the formation of a non-framework anatase phase is almost inevitable; this results in the decomposition of hyperoxide agents and a consequent reduction in the catalytic efficiency. Because of the toxicities of metal fluoride sources and by-products, e.g., $\left(\mathrm{NH}_{4}\right)_{2} \mathrm{TiF}_{6}$, the liquid substitution approach is not an environmentally benign process. Recently, a more simple and tunable solid-state reaction was developed by Tang et al. [14], in which dealuminated microporous $\beta$ zeolite precursors were mixed with $\mathrm{Cp}_{2} \mathrm{TiCl}_{2}$ and then calcined in air to produce microporous Ti- $\beta$ zeolites with various Ti contents. Their use in cyclohexene oxidation showed that the resultant materials were highly active. Here, we further develop this secondary solid-state reaction method for the synthesis of hierarchically structured Ti- $\beta$ zeolites, using presynthesized hierarchically structured $\beta$ zeolites as precursors. To the best of our knowledge, the post-synthesis of hierarchical Ti- $\beta$ by a solid-phase reaction has not been reported previously, and this route is suitable for the scaled-up production of hierarchical Ti- $\beta$ zeolites.

\section{Experimental}

\subsection{Materials}

Cyclohexene (AR) was purchased from Aladdin. 1-Dodecene (AR) was obtained from Acros. Tetraethyl orthosilicate (TEOS, $\mathrm{AR}), \mathrm{NaCl}(\mathrm{AR}), \mathrm{KCl}(\mathrm{AR}), \mathrm{NaAlO}_{2}(\mathrm{AR})$, cetyltrimethylammonium bromide (CTAB, AR), tetraethylammonium hydroxide (TEAOH, AR), $\mathrm{H}_{2} \mathrm{O}_{2}$ (30 wt\%, AR), and all other organic compounds used in the catalytic tests were purchased from Shanghai J\&K, China.

\subsection{Preparation of hierarchical $\beta$ zeolite precursors}

Hierarchical $\beta$ zeolites were prepared according to a previously reported procedure [15]. In a typical run, $\mathrm{KCl}(0.15 \mathrm{~g})$ and $\mathrm{NaCl}(0.05 \mathrm{~g})$ were dissolved in deionized water (20.0 g), and then TEOS (10.4 g, $50 \mathrm{mmol}$ ) and TEAOH (14.4 g, $25 \mathrm{wt} \%$ ) were added to the solution, The mixture was stirred at $313 \mathrm{~K}$ for $30 \mathrm{~min}, \mathrm{NaAlO}_{2}(0.162 \mathrm{~g}, 2 \mathrm{mmol})$ was then added, and the resultant solution was stirred for $4 \mathrm{~h}$ at $313 \mathrm{~K}$. CTAB (1.0 g) dissolved in water $(2.0 \mathrm{~g})$ was added to the emulsion and the reaction solution was continuously stirred at $353 \mathrm{~K}$ for $8 \mathrm{~h}$. The obtained mixture was crystallized in a Teflon-lined autoclave at $423 \mathrm{~K}$ for $48 \mathrm{~h}$. The products were recovered by filtration, washed with deionized water, and dried in air at $373 \mathrm{~K}$. The resultant materials were calcined in air at $823 \mathrm{~K}$ for $7 \mathrm{~h}$ to remove the porous template; a white product, denoted by $\mathrm{H}-m \beta$, was obtained, in which $m$ represents mesoporous structures. Microporous $\beta$ zeolites were prepared in the same way but without CTAB addition.

\subsection{Titanation of hierarchical $\beta$ zeolite}

Ti(IV)-containing hierarchical $\beta$ zeolites (Ti- $m \beta$ ) were prepared using a two-step post-synthesis procedure: dealumination of $\mathrm{H}-m \beta$ zeolites to obtain hierarchical Si- $\beta$ zeolites $(\mathrm{Si}-m \beta)$ and titanation of the dealuminated $\mathrm{Si}-m \beta$ zeolites. In the first step, the synthesized $\mathrm{H}-m \beta$ precursors were treated with 13 mol/L $\mathrm{HNO}_{3}$ solution for $20 \mathrm{~h}$ to remove the $\mathrm{Al}$ atoms in the zeolites [13] and then washed with deionized water until the filtrate $\mathrm{pH}$ was near 7 . In the second step, after drying at $373 \mathrm{~K}$ for $12 \mathrm{~h}$, the resultant $\mathrm{Si}-m \beta$ zeolites were mixed homogeneously with $\mathrm{Cp}_{2} \mathrm{TiCl}_{2}$. Finally, the mixtures were calcined in air at $823 \mathrm{~K}$ for $12 \mathrm{~h}$ to give the final product, i.e., Ti- $m \beta$. The amounts of Ti incorporated into Ti- $m \beta$ were 1,3 , and $5 \mathrm{wt} \%$, and the samples were denoted by Ti- $m \beta-\mathrm{S} 1, \mathrm{Ti}-m \beta-\mathrm{S} 2$, and Ti- $m \beta-\mathrm{S} 3$, respectively. For comparison, microporous Ti- $\beta$, denoted by $\mathrm{Ti}-\mathrm{M} \beta$, with a Ti content similar to that of Ti- $m \beta-\mathrm{S} 2$, was prepared using the same post-synthesis method.

\subsection{Catalytic tests}

The epoxidation of cyclohexene and 1-dodecene was used as model reactions for investigating the performance of the synthesized hierarchical and microporous Ti- $\beta$ zeolites. All the reactions were carried out at $333 \mathrm{~K}$ in $25 \mathrm{~mL}$ three-necked flasks. The reaction products were analyzed using gas chromatography-mass spectrometry (Agilent 6890/5973N with an autosampler and an HP-5ms capillary column). The substrate conversion, product yield, and selectivity were determined from the standard curves of the corresponding material.

In a typical epoxidation of cyclohexene, acetonitrile $(10 \mathrm{~mL})$, cyclohexene ( $5 \mathrm{mmol}$ ), and catalyst (50 $\mathrm{mg}$ ) were mixed in the reaction vessel. When the solution temperature was stable at $333 \mathrm{~K}, \mathrm{H}_{2} \mathrm{O}_{2}$ (7.5 mmol, $30 \mathrm{wt} \%$ ) was injected. Samples were removed at intervals using a microsyringe and diluted with ethanol.

In the epoxidation of 1-dodecene, butan-2-one (10 mL), 1-dodecene (5 mmol), and catalyst (50 mg) were mixed. When the solution temperature reached $333 \mathrm{~K}, \mathrm{H}_{2} \mathrm{O}_{2}(7.5 \mathrm{mmol}, 30$ wt\%) was injected. Samples were removed at intervals using a microsyringe and diluted with ethanol.

\subsection{Characterization}

The zeolites were examined by X-ray diffraction (XRD) with a Rigaku D/Max 2200PC diffractometer, using $\mathrm{Cu} K_{\alpha}$ radiation (40 $\mathrm{kV}$ and $20 \mathrm{~mA}$ ), at a scanning rate of $4^{\circ} / \mathrm{min}$ between $5^{\circ}$ and $50^{\circ}$, in steps of $0.009^{\circ} . \mathrm{N}_{2}$ adsorption-desorption measurements were performed at $77 \mathrm{~K}$ using a Micromeritics Tristar 3000 instrument, and the specific surface area and pore size 


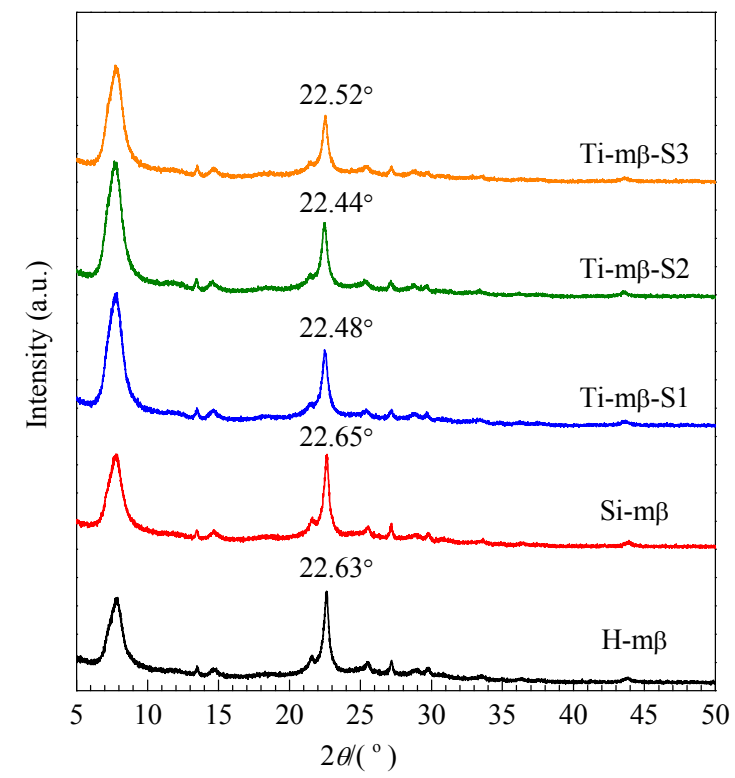

Fig. 1. XRD patterns of $\mathrm{H}-m \beta$, Si $-m \beta$, Ti- $m \beta-\mathrm{S} 1$, Ti- $m \beta-\mathrm{S} 2$, and Ti- $m \beta-\mathrm{S} 3$ samples.

distribution of each sample were calculated by the BET and $\mathrm{BJH}$ methods, respectively. Field-emission scanning electron microscopy (FE-SEM) was performed using a Hitachi SU8220 electron microscope. Field-emission transmission electron microscopy (FE-TEM) and energy disperse spectroscopy (EDS) were performed using a JEOL 200CX electron microscope operated at $200 \mathrm{kV}$. Ultraviolet-visible (UV-vis) absorption spectra were obtained using a UV-3101 PC spectrometer (Shimad$\mathrm{zu}$ ). The compositions of the synthesized materials were determined by inductively coupled plasma atomic emission spectroscopy (ICP-AES) using a Varian Vista AX analyzer. UV-Raman spectra were recorded using a laboratory-made UV-Raman spectrometer with a spectral resolution of $2 \mathrm{~cm}^{-1}$.
Table 1

Textural properties of catalysts studied in this work.

\begin{tabular}{lcccccc}
\hline Sample & Si/Al & $\begin{array}{c}\text { Ti loading } \\
(\mathrm{wt} \%)\end{array}$ & $\begin{array}{c}A_{\mathrm{BET}} \\
\left(\mathrm{m}^{2} / \mathrm{g}\right)\end{array}$ & $\begin{array}{c}A_{\text {mic }}{ }^{\mathrm{a}} \\
\left(\mathrm{m}^{2} / \mathrm{g}\right)\end{array}$ & $\begin{array}{c}V_{\text {tot }}{ }^{\mathrm{b}} \\
\left(\mathrm{cm}^{3} / \mathrm{g}\right)\end{array}$ & $\begin{array}{c}V_{\text {mic }^{\mathrm{a}}} \\
\left(\mathrm{cm}^{3} / \mathrm{g}\right)\end{array}$ \\
\hline $\mathrm{H}-m \beta$ & 23 & 0 & 556 & 379 & 0.374 & 0.175 \\
$\mathrm{Si}-m \beta$ & $>1250$ & 0 & 478 & 340 & 0.347 & 0.157 \\
Ti- $m \beta-\mathrm{S} 1$ & $>1250$ & 1.01 & 524 & 382 & 0.371 & 0.177 \\
Ti- $m \beta-\mathrm{S} 2$ & $>1250$ & 2.91 & 498 & 364 & 0.350 & 0.169 \\
Ti- $m \beta-\mathrm{S} 3$ & $>1250$ & 4.29 & 472 & 347 & 0.320 & 0.161 \\
Ti-M $\beta$ & $>1250$ & 2.61 & 549 & 406 & 0.280 & 0.188 \\
\hline a Determined by $t$-plot method. b Volume adsorbed at $p / p_{0}=0.99$.
\end{tabular}

The line at $266 \mathrm{~nm}$ from the double frequency of a DPSS 532 Model $200532 \mathrm{~nm}$ laser was used as the excitation source, with power on samples of about $8.0 \mathrm{~mW}$.

\section{Results and discussion}

\subsection{Physicochemical properties of synthesized materials}

The crystalline structures and purities of the synthesized samples were determined using XRD, ICP-AES, and SEM. Fig. 1 shows the XRD patterns of $\mathrm{H}-m \beta$, dealuminated $\mathrm{Si}-m \beta$, and titanated Ti- $m \beta$. It is clear that all the samples, including $\mathrm{Si}-m \beta$, which experienced harsh acid-etching, have the characteristic diffraction patterns of BEA-type zeolites and similar diffraction peak intensities, confirming successful synthesis of highly crystalline $\beta$ zeolites with high stabilities. Because the Ti ion is larger than the $\mathrm{Al}$ ion, one of the main diffraction peaks of $\mathrm{H}-m \beta$ at $22.63^{\circ}$ shifts to a lower $2 \theta$ value of about $22.5^{\circ}$, indicating expansion of the crystal lattice and successful incorporation of Ti into the zeolite framework. The same phenomenon has been observed in previous studies of $\mathrm{Fe}, \mathrm{Sn}$, or Ni-containing $\beta$ zeolites $[16,17,18]$. However, as shown in Table 1 , only trace amounts of $\mathrm{Al}$ were detected in the dealuminated and titanated $\beta$ zeolites by ICP-AES.

SEM images of the synthesized samples are shown in Fig. 2.

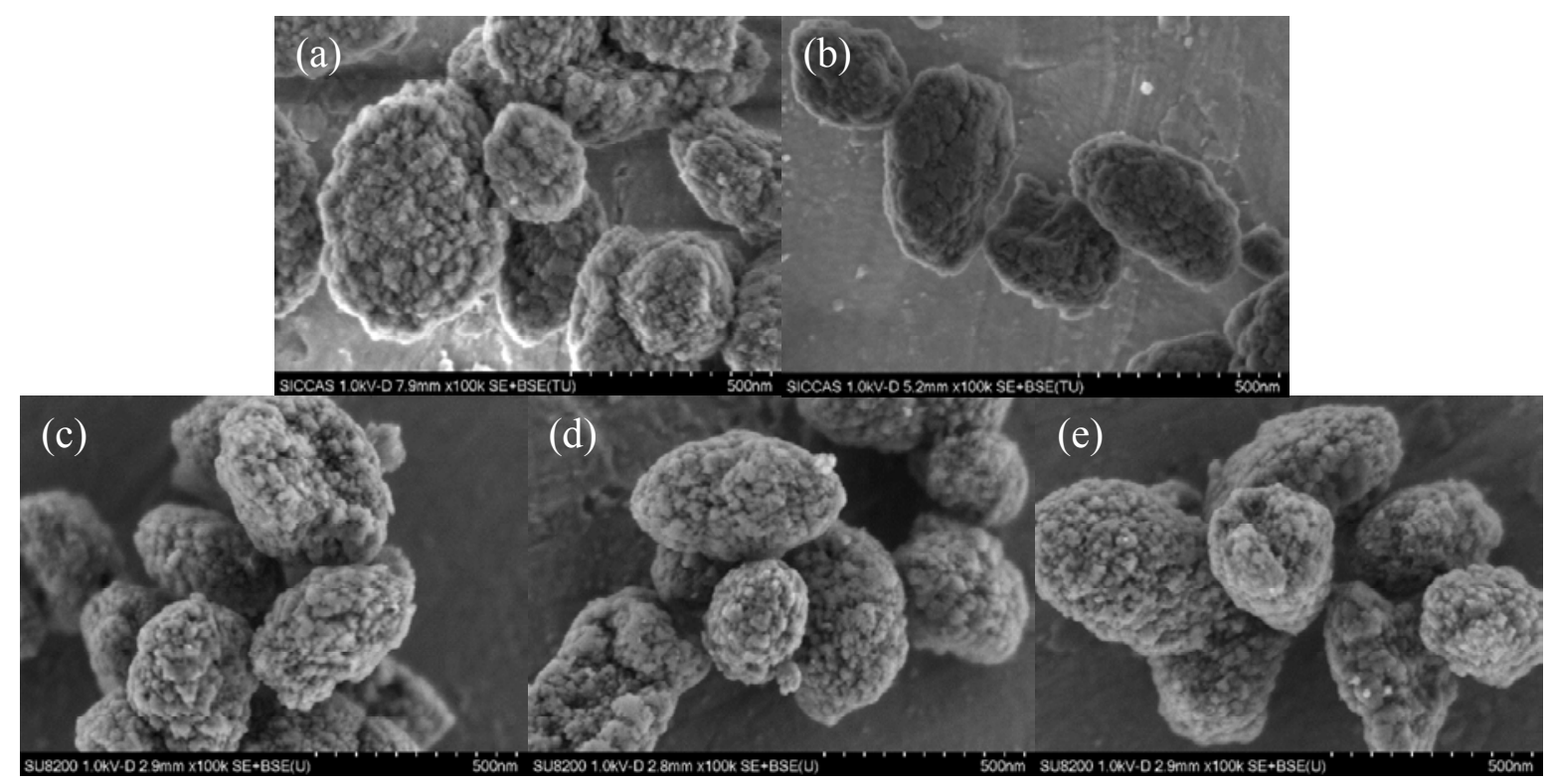

Fig. 2. SEM images of H- $m \beta$ (a), Si- $m \beta$ (b), Ti- $m \beta-\mathrm{S} 1$ (c), Ti- $m \beta-\mathrm{S} 2$ (d), and Ti- $m \beta-\mathrm{S} 3$ (e). 
H- $m \beta$, which consists of tightly stacked nanocrystals, has an ellipsoidal morphology with longitudinal dimensions of 300-600 nm. After dealumination, the morphology of the Si- $m \beta$ zeolites (Fig. 2(b)) remains unchanged and no additional amorphous debris is found. Moreover, all the Ti-m $\beta$ samples (Fig. 2(c)-(e)) show similar morphologies and structures to those of $\mathrm{H}-m \beta$ and Si- $m \beta$, regardless of the Ti contents of the samples. This shows that the synthesized hierarchical $\beta$ zeolites have high structural stabilities and the post-synthesis treatment in the preparation of Ti- $m \beta$ has little impact on the structure; this is consistent with the XRD results.

Fig. 3(a) shows a representative FE-TEM image of Ti- $m \beta-S 2$. The clear lattice fringes show the high crystallinity of the synthesized materials and the clear dark-to-bright contrast confirms the penetration of mesoporous structures within the microporous crystals. Furthermore, energy-dispersive X-ray spectroscopy (Fig. 3(b)) and the corresponding element mappings of Ti- $m \beta-\mathrm{S} 2$ indicate that the post-incorporated Ti atoms are homogeneously distributed in the synthesized materials.

The textural properties of the synthesized materials were determined using $\mathrm{N}_{2}$ adsorption-desorption isotherm analysis.
As shown in Fig. 4(a), all the samples showed type IV isotherms with an increase in the adsorbed amount at a relative pressure of 0.4-0.9; this implies the presence of mesopores in the synthesized materials. In the pore size distribution profiles shown in Fig. 4(b), a peak centered at $3.9 \mathrm{~nm}$ can be observed for all the synthesized hierarchical $\beta$ zeolites. Table 1 summarizes the BET surface areas, pore volumes, and pore sizes $(3.9 \mathrm{~nm})$ of the synthesized materials. All the samples had similar textural properties; this is consistent with the XRD and SEM results, and further proves the effectiveness of this solid-state reaction. The small differences between the volumes and surface areas of H- $m \beta$ and Si- $m \beta$ can be explained by partial deformation of the zeolite frameworks as a result of dealumination under harsh conditions [19]. After the introduction of Ti atoms, these values increased slightly; similar observations have been reported for the post-synthesis of hierarchical Sn- $\beta$ materials [20].

The UV-vis spectra of the synthesized Ti- $m \beta$ are presented in Fig. 5. All the samples show a distinct absorption peak near $220 \mathrm{~nm}$, which is attributed to the ligand-to-metal charge-transfer of isolated [ $\mathrm{TiO}^{4}$ ] or [HOTiO]; the band intensity increases with increasing Ti content. This is direct evidence

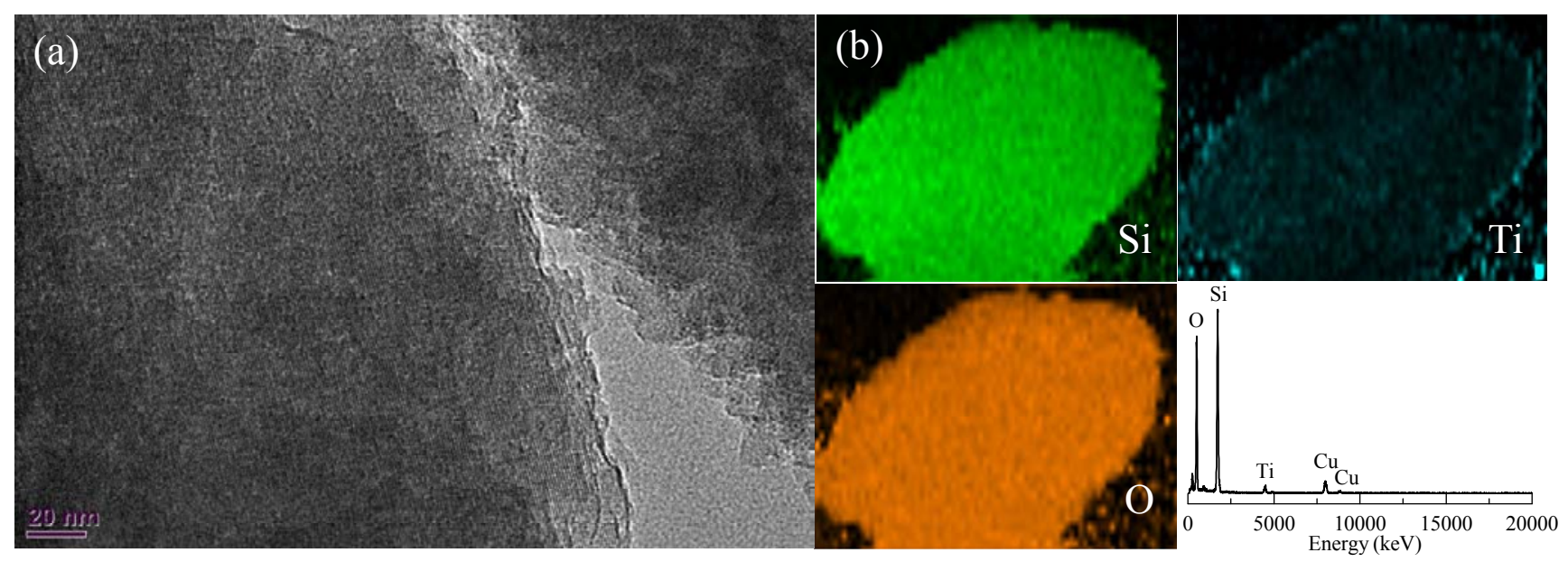

Fig. 3. TEM image of Ti- $m \beta-S 2$ (a) and its element mappings (b).
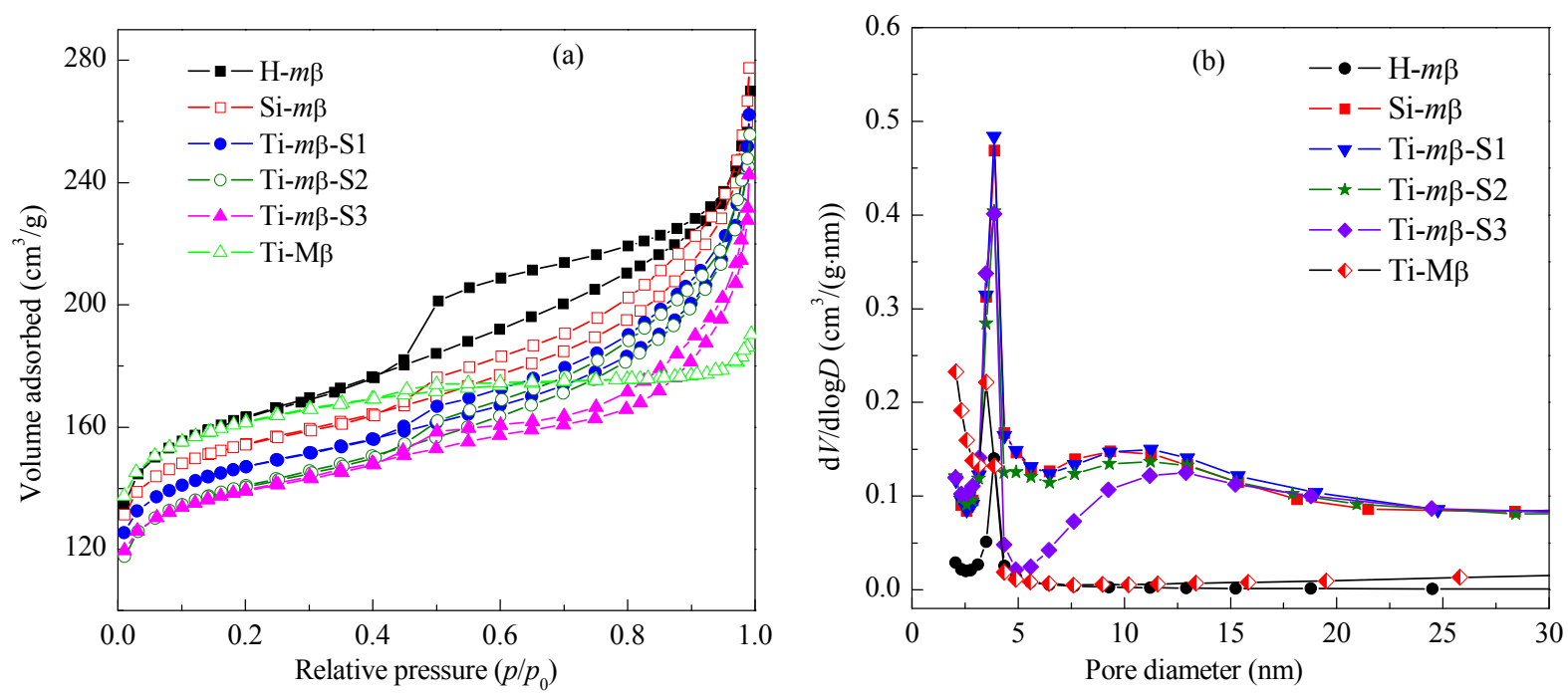

Fig. 4. $\mathrm{N}_{2}$ adsorption-desorption isotherms (a) and pore diameter distributions (b) of synthesized samples. 


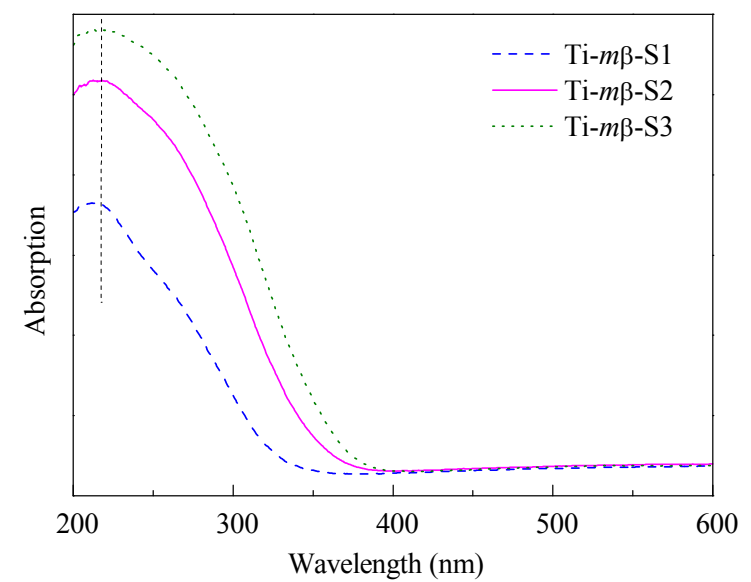

Fig. 5. UV-vis spectra of Ti- $m \beta$ zeolites with various Ti contents.

of the successful incorporation of $\mathrm{Ti}$ atoms into the zeolite frameworks [21]. No significant absorption was observed above $330 \mathrm{~nm}$ in the spectra, which indicates that no bulky $\mathrm{TiO}_{2}$ or Ti-enriched species were formed in the samples [11]. This conclusion is confirmed by UV-Raman spectroscopy. As shown in Fig. 6, there are no distinguishable peaks near 140, 510, and $630 \mathrm{~cm}^{-1}$, which would provide direct evidence of anatase $\mathrm{TiO}_{2}$ [22]. Unlike that of $\mathrm{H}-m \beta$, the UV-Raman spectra of the synthesized Ti- $m \beta$ zeolites clearly show a new band at $1090 \mathrm{~cm}^{-1}$, which is attributed to framework tetrahedrally coordinated $\mathrm{Ti}$ species (Ti-0-Si), based on a previous literature report [23].

\subsection{Catalytic tests}

The catalytic properties of microporous Ti-M $\beta$ and hierarchical Ti- $m \beta$ were investigated in the epoxidation of cyclohexene and 1-dodecene, which have different molecular sizes. As shown in Fig. 7 and Table 2, when cyclohexene was used as the reaction substrate, because of its small molecular size, which allows smooth diffusion in the microporous channels of both the microporous and hierarchical zeolites, microporous Ti-M $\beta$ (Ti 2.61 wt\%) and hierarchical Ti-m $\beta$-S2 (Ti 2.91 wt\%) give similar cyclohexene conversions (57.9\% vs $59.4 \%$ ) and cyclohexene oxide selectivities ( $25.4 \%$ vs $24.2 \%$ ). This indicates that

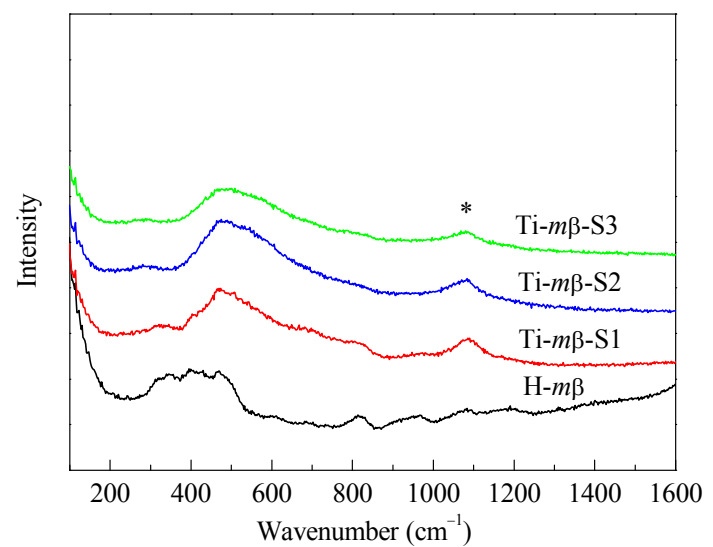

Fig. 6. UV-Raman spectra of $\mathrm{H}-m \beta$ and Ti- $m \beta$ zeolites with various $\mathrm{Ti}$ contents.

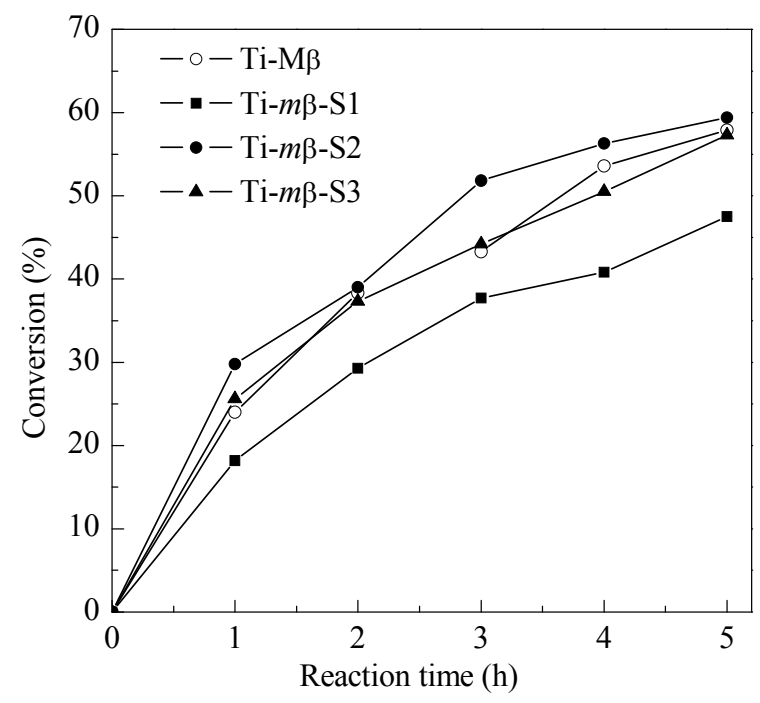

Fig. 7. Cyclohexene conversions in epoxidation on Ti-M $\beta$ and Ti-m $\beta$ zeolites with various Ti contents.

the synthesized hierarchical Ti- $m \beta$ zeolites have intrinsic activities similar to those of their microporous counterparts; this can be understood based on the structural characterization results. The Ti content in the synthesized Ti- $m \beta-\mathrm{S} x$ varies depending on the designed chemical composition. The substrate conversion increased from $47.5 \%$ of Ti- $m \beta-\mathrm{S} 1$ (Ti $1.01 \mathrm{wt} \%$ ) to $59.4 \%$ of Ti- $m \beta-\mathrm{S} 2$ (Ti $2.91 \mathrm{wt} \%$ ), with negligible differences in epoxide product selectivities among the Ti- $m \beta-\mathrm{S} x$ catalysts. However, although Ti- $m \beta$-S3 has the highest Ti content, namely $4.29 \mathrm{wt} \%, 57.3 \%$ cyclohexene conversion was obtained, close to that of $59.4 \%$ for $\mathrm{Ti}-m \beta-\mathrm{S} 2$ (Ti $2.91 \mathrm{wt} \%$ ). This may result from the limited amount of Ti doped in the zeolite frameworks [13]. In contrast, as shown in Table 2, if 1-dodecene is used in the epoxidation reaction, differences between the substrate conversions and epoxide selectivities of microporous Ti-M $\beta$ and hierarchical Ti- $m \beta$-S2 become apparent. Because of the large size of the 1-dodecene molecule, which significantly limits diffusion in the microporous channels, the conversion and epoxide selectivity of microporous Ti-M $\beta$ are as low as $6.8 \%$ and $37.8 \%$, respectively, whereas those of hierarchical Ti- $m \beta$-S2 reach $11.1 \%$ and $60.3 \%$, respectively. These results prove that the introduction of mesoporous structures into zeolites greatly improves the zeolite catalytic performance, especially for reactions involving bulky molecules.

Table 2

Catalytic properties of Ti-M $\beta$ and Ti- $m \beta-\mathrm{S} x$ zeolites in epoxidations of cyclohexene and 1-dodecene.

\begin{tabular}{lcccc}
\hline Catalyst & $\begin{array}{c}\text { Conv. of cyh } \\
\text { a }\end{array}$ & $\begin{array}{c}\text { Sel. for cyh } \\
\text { oxide }^{\mathrm{b}}(\%)\end{array}$ & $\begin{array}{c}\text { Conv. of dod c } \\
(\%)\end{array}$ & $\begin{array}{c}\text { Sel. for } \\
\text { 1,2-epo }{ }^{\mathrm{d}}(\%)\end{array}$ \\
\hline $\mathrm{H}-m \beta$ & - & - & - & - \\
Si- $m \beta$ & - & - & - & - \\
Ti- $m \beta-\mathrm{S} 1$ & 47.5 & 23.2 & - & - \\
Ti- $m \beta-\mathrm{S} 2$ & 59.4 & 24.2 & 11.1 & 60.3 \\
Ti- $m \beta-\mathrm{S} 3$ & 57.3 & 31.8 & - & - \\
Ti-M $\beta$ & 57.9 & 25.4 & 6.8 & 37.8 \\
\hline
\end{tabular}

${ }^{\mathrm{a}} \mathrm{cyh}=$ cyclohexene. ${ }^{\mathrm{b}}$ cyh oxide $=$ cyclohexene oxide. ${ }^{\mathrm{c}}$ dod $=1$-dodecene. d1,2-epo = 1,2-Epoxydodecane. 


\title{
Graphical Abstract
}

Chin. J. Catal., 2015, 36: 906-912 doi: 10.1016/S1872-2067(14)60267-9

Post-synthesis of hierarchically structured Ti- $\beta$ zeolites and their epoxidation catalytic performance

Wenchao Ren, Zile Hua*, Tongguang Ge, Xiaoxia Zhou, Lisong Chen, Yan Zhu, Jianlin Shi*

Shanghai Institute of Ceramics, Chinese Academy of Sciences

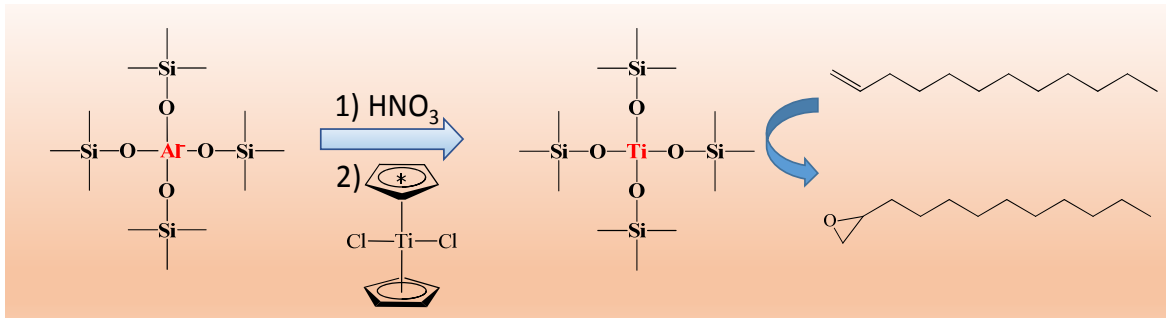

Hierarchical Ti- $\beta$ zeolites were prepared using a two-step post-synthesis procedure. This solid-state procedure is simple and Ti-content tunable. The synthesized hierarchical Ti- $\beta$ zeolites had higher catalytic activities than microporous Ti- $\beta$ in bulky molecule epoxidation.

\section{Conclusions}

A simple and Ti-content-tunable two-step post-synthesis procedure was developed for the preparation of Ti-containing hierarchical $\beta$ zeolites (Ti-m $\beta$ ). UV-vis and UV-Raman spectroscopies showed the presence of a tetrahedrally coordinated Ti(IV) framework. The effects of mesoporous structures and the level of Ti doping on the catalytic activities of Ti- $m \beta$ zeolites were investigated. In the model reaction, namely alkene epoxidation, the synthesized Ti- $m \beta$ zeolites showed high catalytic activities. In particular, when a bulky molecule, i.e., 1-dodecene was used, the benefit of the extra mesoporous structures in Ti- $m \beta$ was significant and the substrate conversion $(11.3 \%)$ was nearly twice that with microporous Ti-M $\beta$ (6.8\%).

\section{References}

[1] Moliner M. Dalton Trans, 2014, 43: 4197

[2] Wu XX, Wang Y Q, Zhang T, Wang S H, Yao P X, Feng W P, Lin Y, Xu J. Catal Commun, 2014, 50: 59

[3] Camblor M A, Corma A, Martinez A, Perez-Pariente J. J Chem Soc, Chem Commun, 1992: 589

[4] Arends I W C E, Sheldon R A, Wallau M, Schuchardt U. Angew Chem Int Ed, 1997, 36: 1145

[5] Bu J, Yun S H, Rhee H K. Korean J Chem Eng, 2000, 17: 76

[6] De Baerdemaeker T, Steenackers B, De Vos D. Chem Commun, 2013, 49: 7474

[7] Wang X X, Li G, Wang W H, Jin C Z, Chen Y Y. Microporous Mesoporous Mater, 2011, 142: 494
[8] Chen L H, Li XY, Tian D, Li Y, Rooke J C, Zhu G S, Qiu S L, Yang X Y, Su B L. Angew Chem Int Ed, 2011, 50: 11156

[9] Zhou J, Hua Z L, Cui X Z, Ye Z Q, Cui F M, Shi J L. Chem Commun, 2010, 46: 4994

[10] Moller K, Yilmaz B, Jacubinas R M, Muller U, Bein T. J Am Chem Soc, 2011, 133: 5284

[11] Xu H, Zhang Y T, Wu H H, Liu Y M, Li X H, Jiang J G, He M Y, Wu P.J Catal, 2011, 281: 263

[12] Han S, Schmitt K D, Schramm S E, Shihabi D S, Chang C D. Inorg Chim Acta, 1995, 229: 81

[13] Hammond C, Conrad S, Hermans I. Angew Chem Int Ed, 2012, 51: 11736

[14] Tang B, Dai W L, Sun X M, Guan N J, Li L D, Hunger M. Green Chem, 2014, 16: 2281

[15] Zhou X X, Chen H R, Sun Y Y, Zhang K, Fan X Q, Zhu Y, Chen Y, Tao G J, Shi J L. Appl Catal B, 2014, 152: 271

[16] Gurgul J, Latka K, Hnat I, Rynkowski J, Dzwigaj S. Microporous Mesoporous Mater, 2013, 168: 1

[17] Tang B, Dai W L, Wu G J, Guan N J, Li L D, Hunger M. ACS Catal, 2014, 4: 2801

[18] Srebowata A, Baran R, Lomot D, Lisovytskiy D, Onfroy T, Dzwigaj S. Appl Catal B, 2014, 147: 208

[19] Wolf P, Hammond C, Conrad S, Hermans I. Dalton Trans, 2014, 43: 4514

[20] Jin J J, Ye X X, Li Y S, Wang Y Q Li L, Gu J L, Zhao W R, Shi J L. Dalton Trans, 2014, 43: 8196

[21] Wang X S, Guo X W. Catal Today, 1999, 51: 177

[22] Krijnen S, Sanchez P, Jakobs B T F, van Hooff J H C. Microporous Mesoporous Mater, 1999, 31: 163

[23] Li C, Xiong G, Liu J K, Ying P L, Xin Q, Feng Z C. J Phys Chem B, 2001, 105: 2993

\section{后处理工艺制备多级孔Ti-BEA沸石及其环氧化催化性能}

\author{
任文超，华子乐 ${ }^{*}$, 葛同广，周晓霞，陈立松，朱 颜，施剑林 ${ }^{\#}$ \\ 中国科学院上海硅酸盐研究所高性能陶瓷和超微结构国家重点实验室, 上海200050
}

摘要: 基于脱铝多级孔BEA沸石与二氯二茂钛的固相反应, 开展了钛掺杂量可调的多级孔Ti-beta后处理工艺制备研究. 对制备的 多级孔Ti-beta样品的理化性质进行了表征, 包括X射线衍射、氮气吸附脱附测试、扫描电镜、透射电镜、紫外可见吸收光谱和紫 外拉曼光谱等. 结果表明, 多级孔BEA沸石具有较好的化学稳定性, 脱铝-钛化的后处理过程未对样品多级孔结构产生明显影响. 
以环己烯和十二烯的烯烃环氧化为探针反应表征了合成多级孔Ti-beta与纯相微孔Ti-beta沸石的催化性能. 结果表明, 在小分子环 己烯的环氧化反应中, 多级孔Ti-beta沸石的催化活性(转化率 $59.4 \%$ )与微孔Ti-beta相当(转化率 $57.9 \%$ ); 但是在较大分子十二烯的 催化反应中, 多级孔结构Ti-beta材料的催化性能(转化率 $11.1 \%$ )明显优于纯相微孔材料(转化率 $6.8 \%$ ), 且产物中环氧化物选择性更 高(分别为 $60.3 \%$ 和 $37.8 \%$ ).

关键词: Ti-beta; 后处理; 多级孔; 环氧化; 沸石

收稿日期: 2014-11-03. 接受日期: 2014-12-15. 出版日期: 2015-06-20.

*通讯联系人. 电话: (021)52412708; 传真: (021)52413122; 电子信箱: huazl@mail.sic.ac.cn

\#通讯联系人. 电话: (021)52412712; 传真: (021)52413122; 电子信箱: j1shi@mail.sic.ac.cn

基金来源：国家重点基础研究发展计划(973计划, 2013CB933200); 国家高技术研究发展计划(863计划, 2012AA062703); 国家杰 出青年科学基金(51225202); 重质油国家重点实验室开放课题(SKLOP201402003).

本文的英文电子版由Elsevier出版社在ScienceDirect上出版(http://www.sciencedirect.com/science/journal/18722067).

\section{《催化学报》为被国际期刊退稿的高质量论文开辟绿色通道}

我们注意到, 国内一些高质量、原创性的研究工作在投稿到国际期刊上时, 经常因语言和写作问题等非科 学因素而被退稿和拖延发表, 甚至会失去原创知识产权, 这个损失是巨大的, 也是非常可惜的!

众所周知, 按国际学术界的共识, 获得论文的首发权并保证拥有研究工作的原创性不在于论文发表在哪个 刊物(只要是国际ISSN挂号的), 而在于谁第一时间抢先发表了工作.

为了保护作者工作的原创性和首发知识产权, 《催化学报》编委会决定为具有一定原创性的论文提供快速 发表的绿色通道. 对于投到国际著名期刊(如Science, Nature, Energy \& Environmental Science, Journal of the American Chemical Society, Angewandte Chemie International Edition, ACS Catalysis和Journal of Catalysis等)上催 化论文的退稿, 如果其创新性较强, 学术质量较高, 仅仅是因为语言和文章写作原因而被退稿, 《催化学报》会 安排其在最近一期上抢时间发表; 如果文章原创性较好, 不存在学风问题, 但有一些理论观点的争议、实验现 象暂时无法得到完美的理论解释, 或者需要进一步补充相关实验数据等, 本刊主编、副主编也会协助作者尽快 修改和发表相关工作.

对于国际著名相关期刊的退稿, 作者需将相应的审稿意见及意见答复等材料一并提交到本刊, 以加快论文 的处理速度. 